\title{
Kidney Cancer pNX TNM Finding v8
}

National Cancer Institute

\section{Source}

National Cancer Institute. Kidney Cancer pNX TNM Finding v8. NCI Thesaurus. Code C140297.

Kidney cancer in which the regional lymph nodes cannot be assessed. (from AJCC 8th Ed.) 